\title{
Uji Kualitas Air Minum Isi Ulang Dengan Parameter Mikrobiologi Di Kelurahan Berngam Kota Binjai
}

\section{Test the Quality of Refilled Drinking Water with Microbiological Parameters in the Kelurahan Berngam Kota Binjai}

\author{
Eka Setiawan Siregar*, Abdul Karim, dan Rahmiati
}

Program Studi Biologi, Fakultas Biologi, Universitas Medan Area, Indonesia

\begin{abstract}
Abstrak
Salah satu pemenuhan kebutuhan air minum yang menjadi alternatif adalah air minum isi ulang. Air minum aman bagi kesehatan apabila memenuhi persyaratan fisika, mikrobiologi, kimiawi, dan radioaktif. Tujuan penelitian ini adalah untuk mengetahui kualitas air minum isi ulang dengan parameter mikrobiologi (coliform dan E.coli) di Kelurahan Berngam Kota Binjai Tahun 2018. Metode penelitian ini yaitu penelitian deskriptif dengan uji laboratorium. Sampel penelitian adalah seluruh populasi depot air minum isi ulang yang berada di Kelurahan Berngam Kota Binjai Tahun 2018. Hasil penelitian diperoleh bahwa tujuh sampel air minum isi ulang di Kelurahan Berngam telah memenuhi kualitas fisik dan kimia sesuai dengan Permenkes R.I. No.492/Menkes/Per/IV/2010. Sedangkan kualitas secara mikrobiologi belum terpenuhi karena mengandung bakteri coliform dan E.coli. Perlu dilakukan penyuluhan dan pengawasan bagi pemilik depot air minum isi ulang oleh Puskesmas demi terwujudnya air minum yang layak bagi masyarakat.
\end{abstract}

Kata Kunci: kualitas, air minum, isi ulang

\begin{abstract}
Refilled drinking water is one of the alternatives for the need of drinking water. Drinking water is safe for health when it meets physical, microbiological, chemical, radioactive requirements. The purpose of this study was to determine the quality of refilled drinking water with microbiological parameters (coliform dan E. coli) in the Berngam Village of Binjai city in 2018. The method of this research was descriptive research with laboratory tests. The research sample is the entire population of refill drinking water depots located in the Berngam Village of Binjai City in 2018. The results of the study showed that seven samples of refilled drinking water in the Berngam Urban Village had fulfilled the physical and chemical quality in according to them Permenkes R.I. No.492/Menkes/Per/IV/2010. While the quality of microbiology has not been fulfilled because it contains coliform and E. coli bacteria. It is recommended that the Puskesmas management provide counseling and monitoring for the owners of refilled drinking water depots in order to realize qualified drinking water for people.
\end{abstract}

Keywords: quality, refilled drinking, water

*E-mail: ekasetiawansiregar0045@gmail.com

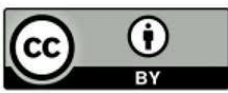


Siregar, E.S., Karim, A. dan Rahmiati, Uji Kualitas Air Minum Isi Ulang Dengan Parameter Mikrobiologi Di Kelurahan Berngam Kota Binjai

\section{PENDAHULUAN}

Air merupakan unsur yang paling penting dalam kehidupan setelah udara. Sekitar tiga per empat bagian dari tubuh kita terdiri dari air dan tidak dapat bertahan hidup lebih dari 4 - 5 hari tanpa minum air. Selain itu, air juga dipergunakan untuk memasak, mencuci, mandi dan membersihkan kotoran yang disekitar rumah. Air juga digunakan untuk keperluan industri, pertanian, pemadam kebakaran, tempat rekreasi, transportasi dan lain - lain. Penyakit - penyakit yang menyerang manusia dapat juga ditularkan dan disebarkan melalui air. Kondisi tersebut tentu dapat menimbulkan wabah penyakit dimana - mana (Chandra, 2014).

Tubuh manusia lebih banyak mengandung air dibandingkan dengan zat - zat lainnya. Hampir seluruh organ dalam tubuh manusia mengandung air, bahkan sampai tulang dan otak sekalipun. Sekitar 55\% - 78\% tubuh manusia mengandung air. Meskipun jumlah kandungan air tidak sama setiap orang, tergantung pada ukuran tubuh manusia, perbedaan umur atau jenis kelamin (Wardani, 2014).

Dalam persyaratan mikrobiologi, air minum yang memenuhi syarat kesehatan harus mempunyai total Coliform dan Coliform tinja yang berjumlah 0/100 ml air. Bakteri Escherichia coli digunakan sebagai petunjuk mikrobiologi air dan dijadikan sebagai indikator pencemaran tinja dalam air (Permenkes, 2010).

Masyarakat selama ini sering mengkonsumsi air yang diambil dari beberapa sumber antara lain dari sumur, pegunungan dan juga dari Perusahaan Daerah Air Minum (PDAM). Semakin majunya teknologi dan diiringi dengan semakin sibuknya aktivitas manusia maka masyarakat cenderung memilih cara yang lebih praktis dan biaya yang relatif lebih murah dalam memenuhi kebutuhan air minum. Salah satu pemenuhan kebutuhan air minum yang menjadi alternative adalah air minum isi ulang (Sebayang dkk, 2015).

Dilihat dari segi harganya, Air Minum Isi Ulang (AMIU) menjadi pilihan bagi masyarakat saat ini. Air minum jenis ini dapat diperoleh di depot dengan harga sepertiga lebih murah dari produk air minum kemasan yang bermerek. Kecenderungan penduduk untuk mengkonsumsi air minum isi ulang demikian besar dan semakin diminati, akan tetapi masyarakat masih ragu dalam menentukan kualitasnya sehingga perlu dilakukan pengawasan dan pembinaan terhadap usaha depot air minum isi ulang (Mirza, 2014). 
Beberapa hal yang dapat mempengaruhi kualitas air minum isi ulang yaitu hygiene dan sanitasi depot, sarana pengolahan, dan proses pengolahan air minum isi ulang. Proses pengolahan air minum isi ulang yang saat ini dilakukan diberbagai depot yang ada di masyarakat yaitu proses ozonisasi, ultraviolet (UV), dan reversed osmosis (RO) (Latif, 2012).

Proses pengolahan air pada depot air minum pada prinsipnya adalah filtrasi (penyaringan) dan desinfeksi. Proses filtrasi dimaksudkan selain untuk memisahkan kontaminan tersuspensi juga memisahkan campuran yang berbentuk koloid termasuk mikroorganisme dari dalam air, sedangkan desinfeksi dimaksudkan untuk membunuh mikroorganisme yang tidak tersaring pada proses sebelumnya (Pradana dan Marsono, 2013).

\section{METODE PENELITIAN}

Penelitian dilakukan di Balai Teknik Kesehatan Lingkungan dan Pengendalian Penyakit (BTKLPP) Kelas I Medan tahun 2018. Penelitian dilakukan dengan metode eksperimental dengan menguji kualitas air minum isi ulang dengan secara mikrobiologi. Analsis mikrobiologi dilakukan dengan metode most probable number (Lay, 1994). Data penelitan akan ditampilkan dalam bentuk tabulasi data dan dianalisis secara deskriptif.

\section{SAMPEL PENELITIAN}

Sampel penelitian adalah air minum isi ulang yang diperoleh dari depot air minum isi ulang di Kelurahan Berngam Kota Binjai, Sampel diperoleh dari tujuh DAM (S01, S02, S03, S04, S05, S06, dan S07) yang berada di Kelurahan Berngam Kota Binjai.

\section{HASIL DAN PEMBAHASAN}

Hasil penelitian menunjukkan bahwa ketujuh sampel air minum isi ulang memenuhi syarat fisik sebagai air minum yang layak dikonsumsi. Hal ini sesuai dengan syarat baku mutu air minum pada Permenkes RI No.492/Menkes/Per/IV/2010. Parameter fisik yang diamati meliputi bau, warna, rasa, suhu, dan nilai $\mathrm{pH}$.

Secara mikrobiologi (berdasarkan deteksi keberadaan bakteri coliform dan E. coli) hasil penelitian menunjukkan bahwa ketujuh sampel tidak memenuhi syarat secara mikrobiologi. Data tersaji pada tebl 1.

Tabel 1. Data hasil uji kualitas air minum isi ulang secara mikrobiologis

\begin{tabular}{ccc}
\hline Kode sampel & Bakteri coliform (per 100 ml sampel) & Eschericia coli \\
\hline S01 & per $100 \mathrm{ml}$ sampel) \\
S02 & 22,0 & $<1,1$ \\
& $>22$ & $>23$ \\
\hline
\end{tabular}


Siregar, E.S., Karim, A. dan Rahmiati, Uji Kualitas Air Minum Isi Ulang Dengan Parameter Mikrobiologi Di Kelurahan Berngam Kota Binjai

\begin{tabular}{lcc}
\hline S03 & $>23$ & $>23$ \\
S04 & $>23$ & $>23$ \\
S05 & $>23$ & 3,60 \\
S06 & $>23$ & $>23$ \\
S07 & $<1,1$ & $<1,1$ \\
\hline
\end{tabular}

Berdasarkan hasil uji laboratorium terhadap tujuh sampel air minum isi ulang terdapat lima sampel mengandung Coliform sebesar >23 MPN/100 dan dua sampel sebesar 22,0 dan $<1,1$ serta empat dari tujuh sampel mengandung E. coli sebesar $>23$ MPN/100 dan satu sampel sebesar 3,6 dan dua sampel sebesar $<1,1$.

Dari hasil tersebut diketahui bahwa air minum isi ulang di Kelurahan Berngam tidak memenuhi syarat menurut parameter mikrobiologi berdasarkan Permenkes RI No.492/Menkes/Per/IV/2010 tentang persyaratan kualitas air minum karena kadar maksimum total Coliform yang diperbolehkan adalah 0/100 ml sampel dan kadar maksimum E. coli yang diperbolehkan adalah 0/100 ml sampel.

\section{SIMPULAN}

Dari penelitian yang dilakukan dapat disimpulkan bahwa sebanyak tujuh sampel air minum asal depot air minum isi ulang di Kelurahan Berngam Kota Binjai memuhi kualitas fisik tetapi tidak memenuhi kualitas mikrobiologis untuk air minum sesuai dengan standar baku mutu air minum pada Permenkes RI No.492/Menkes/Per/IV/2010.

\section{DAFTAR PUSTAKA}

Chandra B. (2014). Pengantar Kesehatan Lingkungan. EGC Buku Kedokteran: Jakarta.

Latif, Iin Wahyuni. (2012). Studi Kualitas Air Minum Isi Ulang Ditinjau dari Proses Ozonisasi, Ultraviolet dan Reversed Osmosis Di Kecamatan Kota Tengah dan Kecamatan Kota Selatan Kota Gorontalo. Skripsi Jurusan Kesehatan Masyarakat Fakultas Ilmu-ilmu Kesehatan dan Keolahragaan, Universitas Gororntalo.

Permenkes RI. (2014). Permenkes No 43 Tahun 2014 tentang Hygiene Sanitasi Depot Air Minum, Kemenkes RI, Jakarta.

Pradana dan Marsono. (2013). Uji Kualitas Air Minum Isi Ulang di Kecamatan Sukodono, Sidoarjo Ditinjau dari Perilaku dan Pemeliharaan Alat. Jurnal Teknik Pomits.1(2): 22 - 34.

Sebayang P et al. (2015). Teknologi Pengolahan Air Kotor dan Payau Menjadi Air Bersih. Gosyen Publishing, Yogyakarta

Wardani RA. (2014). Terapi Kesehatan \& Kecantikan dengan Air Putih. Jurnal Kesehatan Yogyakarta. 2 (2): 83 - 86 . 